\title{
Instructional videos: an intervention to an effective mathematics instruction
}

\author{
Hazel V. Bunag \\ madamhazel94@gmail.com \\ Laguna State Polytechnic University, Sta. Cruz, Laguna 4009 Philippines
}

\begin{abstract}
This study attempted to (1) identify the learners' level of understanding of the different Mathematics concepts, (2) devise instructional videos, (3) identify the learners' perception of the instructional videos in terms of its (a) purpose, (b) content and (c) video quality and to (4) ascertain whether there is a significant difference in the learners' level of understanding before and after the intervention.

This employed an experimental approach of research that made use of the devised instructional videos, achievement test and survey questionnaire. The respondents were one hundred (100) learners of Buenavista Integrated National High School. It is determined that the use of the instructional videos gives a highly significant difference in the improvement of the learners' understanding. Also, the feedback survey questionnaire also gained highly favourable results. With regards to the instructional videos' purpose, it was generalized that it was very helpful to achieve the standards set by the department. Meanwhile, it was also found out that in terms of the content of the tool, the learners noted that the activities, examples, and exercises are appropriate and suits all types of learners with varying backgrounds. Moreover, the video is identified to be in high resolution and quality, not affecting its performance while being presented and watched. Overall, the impact of the instructional videos to the learners' attitude towards learning and its effect on the achievement of the competencies are highly favourable.
\end{abstract}

Keywords: Intructional Videos; Mathematics; Mathematics Instruction; Video Lessons; Technology in Mathematics

\section{Introduction}

One of the core academic subjects throughout the world, Mathematics, is key to many of our most common daily activities and routines. Further, in today's increasingly technologically reliant society, more and more jobs require some level of proficiency in mathematics and science. Students who lack sufficient mathematical knowledge and skills are more likely to experience negative outcomes as adults, including fewer opportunities for meaningful employment and a reduced likelihood of economic independence. Because of these factors, it is critical that students begin to develop essential math concepts and skills at an early age. From the practical perspective, mathematical tasks are the bedrock of mathematics lessons in many countries (Watson \& Ohtani, 2015). Mathematics classroom instruction is normally organized and delivered through the activities in mathematical tasks developed by teachers or found in curriculum materials. In other words, mathematics instructions are information guiding students how to carry out the activities in the mathematical task. They may take different forms, but typically, as a series of step-by-step procedure and guiding questions that prompt students to explore and discover the mathematical concepts embodied in the task. To examine classroom instructions, it is common to look at and analyze the amount of lesson time that students spend on doing the task (Shimizu, Kaur, Huang, \& Clarke, 2010). Watson and Ohtani (2015) also point out, from the cognitive viewpoint, that the goal and content of a mathematical task are important and can have significant effect on students' learning.

On the other hand, most of our learners today perceive that Mathematics is a challenging subject to master, from primary school to university (Shafie, Shahdanb \& Liew, 2010). Most students think that numbers alone are hard to understand because numbers have its own language. But numbers mixed with a foreign language is much harder to understand and analyze. The Authorities in Mathematics concur that attaining Mathematics' conceptual understanding and procedural skills encompasses various cognitive processes (Watson \& Gable, 2012).

The researcher believed that these learning processes involves the use of technology in teaching Mathematics. These learning processes are assumed to be directly related to successful outcomes that are further linked to achievement outcomes. It is also considered that choosing the appropriate method of teaching Mathematics has a great effect in achieving the learning goals of the students.

In 2012, the Department of Education of the Philippines embraced the K-12 curriculum, which means that the Philippine Basic Education is to observe the kindergarten plus twelve years to complete its Basic Education Program (DepEd, 2012). This move was taken because of the poor quality of the Philippine Basic Education as reflected by the low achievement scores of Filipino students in the National Achievement Test and the international test known as the Third International 
Mathematics and Science Study (TIMSS) (DepEd, 2012). Also, it was believed that Philippines was one of the countries in Asia that still has a ten-year basic education making an impression that the quality of education in the country is not so high.

Despite the low performance of the Filipino learners and the diversity of the Philippine classroom situations, some researches revealed the positive side of the poor performing Filipino students, such as that Filipino students highly enjoyed learning in different ways in different settings; that Filipino students were made ready and prepared to learn the expected outcomes set by the curriculum makers and implementers and that the effort of Filipino learners, especially the young generation, could greatly help in elevating their ability and skills to learn Mathematics. Having these stated, it can be implied that Filipino students are eager and willing to learn despite the low performance as reflected in the result of the annual TIMSS. Therefore, advantages of Filipino learners were also reflected in the study conducted by the Third International Mathematics and Science Study. On the other hand, the implementation of the currently existing Modular Distance Learning in most of the schools in the country made learning a bit more challenging. The sudden change in the teaching-learning process affected not only the teachers but also the learners and their parents. Considering that the department had already studied almost all the possible solutions to the problems that might arise, we cannot disregard the fact that our learners need more personalized teaching techniques that are tailored for their learning types and styles and we, as teachers, are responsible for ensuring that our learners would really learn even remotely, may it be synchronous or asynchronous. The chosen locale of this study was found out to be performing lower than the average during the first quarter of the implementation of the Modular Distance Learning. The printed modules provided by the regional offices, the learning activity sheets, and some supplemental activities made the teachers to provide learning despite their differences, given to the learners were found as deficient to achieve the standards of learning as reflected in their scores, assessment results and final quarter grades. This is followed by the idea that teachers should do more intervention activities or projects to ensure that our learners receive enough information to use in their future.

Based on the foresaid premises, there exist a conflict between Mathematics instruction and the level of achievement of the learners which, in time, might result to a greater negative effect on the learners' successful achievement of expected learning outcomes and how they could use these concepts in real life situations. Because of this, the researcher decided to conduct a study on determining the learners' level of achievement in Mathematics and devise a tool for intervention to add to the possible effective intervention tools that teachers may use to facilitate learning, especially in Mathematics.

\subsection{Conceptual framework}

Teaching-learning process undergoes through different tasks to achieve effective learning of the students. As years passed by, many educational philosophers formulated different teaching strategies to help improve the understanding of the students. Among these strategies, there is no one strategy that is considered the best (Bunag, 2015). The researcher then considered it necessary to conduct a study on the effect of having a barrier between Language and Mathematics and create an intervention tool for the enhancement of the learners' level of achievement in Mathematics. As a result, learners are expected to gain a higher level of understanding on the different mathematical terms on the topics discussed during the seventh grade, as well as teachers having an additional strategy to impart the meaning of the mathematical terms to their learners in an easier way.

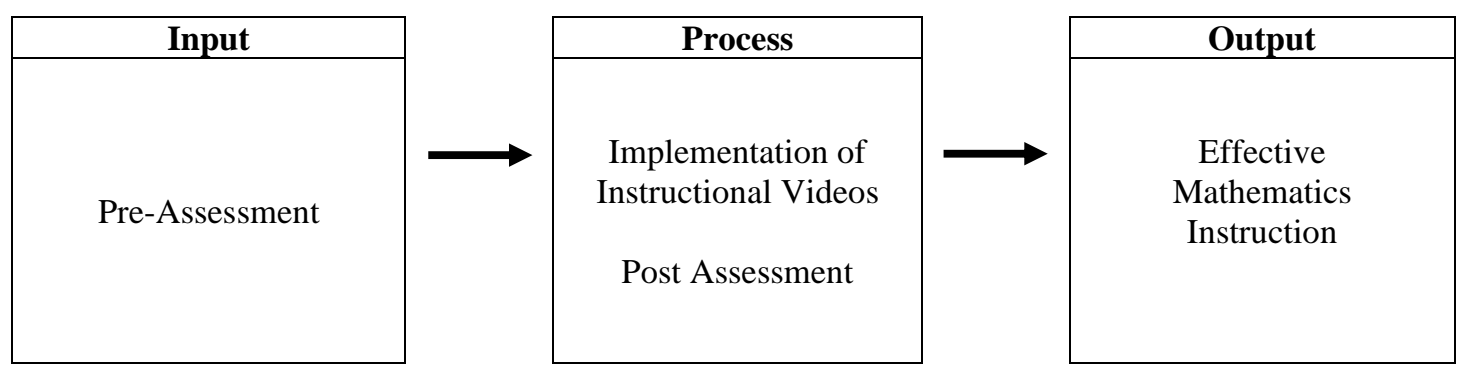

Fig. 1. A Diagram on the Effective Mathematics Instruction as a Result of the Tool for Intervention 


\subsection{Statement of the problem}

This study aimed to determine the learners' level of achievement of the different Mathematics concepts and devise a tool for intervention to add to the possible effective tools to facilitate learning.

Specifically, it sought to achieve the following objectives:

1. Identify the learners' level of understanding of the different Mathematics concepts

2. Devise instructional videos

3. Identify the learners' perception of the instructional videos in terms of its:

3.1 Purpose

3.2 Content

3.3 Video Quality

4. Ascertain whether there is a significant difference in the learners' level of understanding before and after the intervention.

\section{Methodology}

\subsection{Research design}

This study used an assessment test questionnaire which was developed and validated for the collection of data regarding the students' level of understanding the different Mathematical concepts. Afterwards, a tool for intervention was created which was tested for effectiveness in the same group of respondents.

An experimental method of research was used in the study to gather information on the validity of the created tool for intervention. It also dealt with the process of comparing the results of the achievement tests to determine whether there is a significant difference on the performances of the group after applying the intervention. The data were gathered using an assessment test type of questionnaire.

\subsection{Participants of the study}

The respondents of the study were one hundred (100) Grade 9 students from Buenavista Integrated National High School in Magdalena, Laguna. The students have different levels of mental ability. The respondents were chosen purposively since the study is primarily focused in determining the level of understanding of the different Mathematics concepts and devise a tool for intervention. It is believed that they were the ones who can give the appropriate data necessary for the interpretation of the results.

\subsection{Instrumentation}

The researcher utilized an assessment type of questionnaire and a survey questionnaire to gather data after the application of the tool for intervention. The questionnaires were constructed by the researcher and were submitted to her adviser for comments and suggestions on the layout and statement structures. Then the researcher sought help from experts for further suggestions on the appropriate constructions and content. The initial draft of the questionnaires was tried out to twenty (20) Grade 9 students from Buenavista Integrated National High School. Favourable findings would show confirmation that the questionnaire is valid.

\subsection{Data gathering procedure}

The study was concerned with devising and validating the proposed instructional videos in Mathematics considering the level of understanding of learners. The researcher first secured the approval of the concerned authorities before conducting the study. After securing the letters needed, permission from the research adviser was sought. An achievement test was conducted to determine the learners' level of understanding on the different mathematical concepts which become the basis in devising a tool for intervention. The effectiveness of the tool was measured.

For more reliable and valid results, the following steps were done by the researcher:

A fifty-item assessment test was constructed. The content of the assessment was based on the second quarter competencies provided in the $\mathrm{K}$ to 12 Curriculum Guide. The research adviser and selected Mathematics teachers from Buenavista Integrated National High School were asked to check the content of the test in terms of the distribution of questions, grammar and accuracy of content of the test before administration. The test was administered to the respondents after validation. This helped in the collection of data to determine whether there is really an improvement in the learners' achievement. 
The learners' level of understanding, as reflected in the pre-assessment results, was the basis of the depth and width of each instructional video of each mathematical concept. Learners' skills and level of understanding was the main consideration for the creation of the instructional videos. Validation of the tool was done before administering the tool to the learners. Through the comments and suggestions of the evaluators, the content was improved. After validation, the instructional videos were administered to the selected Grade 9 learners in Buenavista Integrated National High School.

A thirty-item survey questionnaire was developed divided into three parts to assess the effectivity of the instructional videos in terms of its purpose, content, and quality. Validation of the survey questionnaire was done before administering the tool to the learners. Through the comments and suggestions of the evaluators, the content was improved. After validation, the survey questionnaire was administered to the selected Grade 9 learners in Buenavista Integrated National High School.

\subsection{Data analysis}

The data collected were tallied, tabulated, analysed, and interpreted. To compare the pre-test and post-test scores of the learners and to see whether there is a significant difference in the mean scores, one-tailed Paired Samples t-Test was used. To determine the learners' level of perception of the instructional videos, the formula for the weighted mean was used.

\section{Results and discussion}

Table 1. Frequency and mean distribution of responses based on the purpose of the instructional videos

\begin{tabular}{|c|c|c|c|c|c|c|c|c|c|}
\hline \multirow{2}{*}{ Statements } & \multicolumn{2}{|c|}{$\mathbf{S A}$} & $\mathbf{A}$ & \multicolumn{3}{|c|}{$\mathbf{N}$} & \multirow{2}{*}{$\begin{array}{l}\text { Weighted } \\
\text { Mean }\end{array}$} & \multirow{2}{*}{$\begin{array}{l}\text { Standard } \\
\text { Deviation }\end{array}$} & \multirow{2}{*}{$\begin{array}{c}\text { Descriptive } \\
\text { Rating }\end{array}$} \\
\hline & $f$ & $\%$ & $f$ & $\%$ & $f$ & $\%$ & & & \\
\hline $\begin{array}{l}\text { The Most Essential Learning } \\
\text { Competencies (MELCs) are } \\
\text { stated in each instructional } \\
\text { video. }\end{array}$ & 100 & 100 & 0 & 0 & 0 & 0 & 5.00 & 0.0000 & SA \\
\hline $\begin{array}{l}\text { The learning objectives are } \\
\text { stated in each instructional } \\
\text { video. }\end{array}$ & 100 & 100 & 0 & 0 & 0 & 0 & 5.00 & 0.0000 & SA \\
\hline $\begin{array}{l}\text { The learning objectives are } \\
\text { aligned to the learning } \\
\text { competencies. }\end{array}$ & 98 & 98 & 2 & 2 & 0 & 0 & 4.98 & 0.1407 & SA \\
\hline $\begin{array}{l}\text { The activities in the } \\
\text { instructional videos are } \\
\text { aligned to the MELCs and } \\
\text { learning objectives. }\end{array}$ & 96 & 96 & 4 & 4 & 0 & 0 & 4.96 & 0.1969 & SA \\
\hline $\begin{array}{l}\text { The examples discussed in } \\
\text { the instructional videos leads } \\
\text { to the achievement of the } \\
\text { MELCs. }\end{array}$ & 99 & 99 & 1 & 1 & 0 & 0 & 4.99 & 0.1000 & SA \\
\hline $\begin{array}{l}\text { The instructional videos } \\
\text { helped me increase my } \\
\text { learning of the different } \\
\text { topics discussed. }\end{array}$ & 100 & 100 & 0 & 0 & 0 & 0 & 5.00 & 0.0000 & SA \\
\hline $\begin{array}{l}\text { I made progress towards } \\
\text { achieving the learning } \\
\text { competencies. }\end{array}$ & 100 & 100 & 0 & 0 & 0 & 0 & 5.00 & 0.0000 & SA \\
\hline $\begin{array}{l}\text { The instructional videos } \\
\text { helped me think } \\
\text { independently about the } \\
\text { subject matter. }\end{array}$ & 95 & 95 & 2 & 2 & 3 & 3 & 4.92 & 0.3674 & SA \\
\hline $\begin{array}{l}\text { The instructional videos } \\
\text { actively involved me in the } \\
\text { process of learning. }\end{array}$ & 95 & 95 & 3 & 3 & 2 & 2 & 4.93 & 0.3258 & SA \\
\hline $\begin{array}{l}\text { I was challenged to achieve } \\
\text { the learning competencies in } \\
\text { the duration of the }\end{array}$ & 97 & 97 & 1 & 1 & 2 & 2 & 4.95 & 0.2973 & SA \\
\hline
\end{tabular}


implementation of the instructional videos.

\begin{tabular}{llll} 
Average & 4.97 & 0.1428 & $S A$ \\
\hline
\end{tabular}

The table shows that the respondents strongly agree that the purpose of the instructional videos are clearly stated (statements 1 and 2, both $M=5$ and $S D=0$ ). The Most Essential Learning Competencies and learning objectives chunked from the MELCs are aligned to each other to ensure the attainment of both $(M=4.98, S D=0.1407)$. The learners also strongly agree that the activities $(M=4.96, S D=0.1969)$ and examples $(M=4.99, S D=0.1000)$ used and discussed in the instructional videos are also aligned to the competencies and objectives set by the department. The results also shows that the tool for intervention helped them increase their learning of the different topics discussed $(M=5$ and $S D=0)$ and helped them make progress towards achieving the competencies $(M=5$ and $S D=0)$. Majority of the learners strongly agrees that the videos helped them think independently $(M=4.92, S D=0.3674)$, get actively involved in the learning process $(M=4.93$, $S D=0.3258)$ and was challenged to achieve the learning competencies $(M=4.95, S D=0.2973)$ during the implementation of the tool for intervention. Overall, the results averaged to 4.97 with a standard deviation of 0.1428 and translates to a rating of Strongly Agree. These results implies that the learners have a positive feedback in terms of the purpose of the instructional videos they had watched to aid to the betterment of their Mathematics learning.

Parallel to the study of Mathumbu, D., Rauscher, W., \& Braun, M. (2014) which sought to investigate and classify lesson objectives framed or implied by teachers in their lesson plans according to knowledge and cognitive process dimensions, it was concluded that the importance of clear lesson objectives should be emphasized and that assessments planned for such lessons should closely match the lesson objectives. A clearly stated lesson objective is considered an essential component of a well-planned lesson.

Table 2. Frequency and mean distribution of responses based on the content of the instructional videos

\begin{tabular}{|c|c|c|c|c|c|c|c|c|c|}
\hline \multirow{2}{*}{ Statements } & \multicolumn{2}{|c|}{ SA } & \multicolumn{2}{|c|}{$\mathbf{A}$} & \multicolumn{2}{|c|}{$\mathbf{N}$} & \multirow{2}{*}{$\begin{array}{c}\text { Weighted } \\
\text { Mean }\end{array}$} & \multirow{2}{*}{$\begin{array}{l}\text { Standard } \\
\text { Deviation }\end{array}$} & \multirow{2}{*}{$\begin{array}{c}\text { Descriptive } \\
\text { Rating }\end{array}$} \\
\hline & $f$ & $\%$ & $f$ & $\%$ & $f$ & $\%$ & & & \\
\hline $\begin{array}{l}\text { The instructional video gave } \\
\text { meaning to the written } \\
\text { materials on the Self-learning } \\
\text { modules (SLMs). }\end{array}$ & 100 & 100 & 0 & 0 & 0 & 0 & 5.00 & 0.0000 & SA \\
\hline $\begin{array}{l}\text { The instructional video } \\
\text { helped me better understand } \\
\text { the content of the SLMs. }\end{array}$ & 98 & 98 & 2 & 2 & 0 & 0 & 4.98 & 0.1407 & SA \\
\hline $\begin{array}{l}\text { I was able to learn } \\
\text { information from the } \\
\text { instructional videos as well } \\
\text { as I would have in a face-to- } \\
\text { face discussion. }\end{array}$ & 100 & 100 & 0 & 0 & 0 & 0 & 5.00 & 0.0000 & SA \\
\hline $\begin{array}{l}\text { The instructional videos } \\
\text { helped me practice the } \\
\text { written content of the SLMs. }\end{array}$ & 98 & 98 & 2 & 2 & 0 & 0 & 4.98 & 0.1407 & SA \\
\hline $\begin{array}{l}\text { The difficulty of the } \\
\text { instructional videos is } \\
\text { applicable to all types of } \\
\text { learners. }\end{array}$ & 93 & 93 & 3 & 3 & 4 & 4 & 4.89 & 0.4239 & SA \\
\hline $\begin{array}{l}\text { The instructional videos } \\
\text { considered the diverse } \\
\text { cultural differences of the } \\
\text { learners. }\end{array}$ & 92 & 92 & 4 & 4 & 4 & 4 & 4.88 & 0.4330 & SA \\
\hline $\begin{array}{l}\text { The pace of the lessons in } \\
\text { each instructional video are } \\
\text { well-planned and distributed } \\
\text { accordingly. }\end{array}$ & 96 & 96 & 2 & 2 & 2 & 2 & 4.94 & 0.3120 & SA \\
\hline $\begin{array}{l}\text { The instructional videos } \\
\text { stimulate participation even } \\
\text { remotely. }\end{array}$ & 95 & 95 & 2 & 2 & 3 & 3 & 4.92 & 0.3674 & SA \\
\hline The number of activities is & 98 & 98 & 2 & 2 & 0 & 0 & 4.98 & 0.1407 & SA \\
\hline
\end{tabular}


just enough to achieve full understanding of the subject matter.

The subject matter is $\begin{array}{lllllllllll}\text { discussed and applied to real- } & 99 & 99 & 1 & 1 & 0 & 0 & 4.99 & 0.1000 & \text { SA }\end{array}$ life situations.

\begin{tabular}{llll} 
Average & 4.96 & 0.2058 & $S A$ \\
\hline
\end{tabular}

As illustrated in the table above, the learners strongly agree that the instructional videos gave meaning to the written materials on the self-learning modules $(M=5, S D=0)$ distributed by the department. It is also agreed that it helped them better understand its content $(M=4.98, S D=0.1407)$ and that they were able to acquire information from the videos as it would have been in a face-to-face class $(M=5, S D=0)$. Furthermore, the results also shows that it helped them practice the written content $(M=4.98, S D=0.1407)$ especially the computations. When it comes to the difficulty of the content, the respondents strongly agrees that it is applicable to all types of learners $(M=4.89, S D=0.4239)$ and also considers the cultural differences $(M=4.88, S D=0.4330)$. On the other hand, the pace of the lessons in each instructional video is also strongly agreed to be well-planned and distributed accordingly $(M=4.94, S D=0.3120)$ and that these stimulates participation even remotely $(M=4.92, S D=0.3674)$. It is also noted that the activities discussed in the videos are enough to achieve full understanding of the subject matter $(M=4.98, S D=0.1407)$ and can be applied to real-life $(M=4.99, S D=0.1000)$. Overall, the instructional videos gained an average of 4.96 with a standard deviation of 0.2058 which translates to strongly agree in terms of its content. The results show that the learners positively perceive the intervention tool.

In a book written by Richards, J. C., \& Bohlke, D. (2011) entitled Creating Effective Language Lessons, it was stated that even if you are teaching from a textbook or online, further planning is usually necessary to adapt the textbook to the teaching context online and to supplement it based on the learners' backgrounds, interests, learning styles, and abilities. You will need to think about the resources you will use in the lesson as well as how much time you will spend on different activities. Your plan may also include ideas on how you will monitor your students' understanding and learning.

Table 3. Frequency and mean distribution of responses based on the quality of the instructional videos

\begin{tabular}{|c|c|c|c|c|c|c|c|c|c|}
\hline \multirow{2}{*}{ Statements } & \multicolumn{2}{|c|}{$S A$} & \multicolumn{2}{|c|}{$A$} & \multicolumn{2}{|c|}{$N$} & \multirow{2}{*}{$\begin{array}{c}\text { Weighted } \\
\text { Mean } \\
\end{array}$} & \multirow{2}{*}{$\begin{array}{l}\text { Standard } \\
\text { Deviation }\end{array}$} & \multirow{2}{*}{$\begin{array}{c}\text { Descriptive } \\
\text { Rating } \\
\end{array}$} \\
\hline & $f$ & $\%$ & $f$ & $\%$ & $f$ & $\%$ & & & \\
\hline $\begin{array}{l}\text { The video itself is presented } \\
\text { in a high-quality format. }\end{array}$ & 100 & 100 & 0 & 0 & 0 & 0 & 5.00 & 0.0000 & SA \\
\hline $\begin{array}{l}\text { The voice of the teacher in } \\
\text { the instructional videos is } \\
\text { loud and clear. }\end{array}$ & 100 & 100 & 0 & 0 & 0 & 0 & 5.00 & 0.0000 & SA \\
\hline $\begin{array}{l}\text { The video and the voice over } \\
\text { play synchronously. }\end{array}$ & 100 & 100 & 0 & 0 & 0 & 0 & 5.00 & 0.0000 & SA \\
\hline $\begin{array}{l}\text { The file size of the } \\
\text { instructional videos is enough } \\
\text { to play it even on outdated } \\
\text { gadgets while still } \\
\text { maintaining its quality. }\end{array}$ & 100 & 100 & 0 & 0 & 0 & 0 & 5.00 & 0.0000 & SA \\
\hline $\begin{array}{l}\text { The duration of the } \\
\text { instructional videos is well- } \\
\text { considered to maintain } \\
\text { learners' attention. }\end{array}$ & 100 & 100 & 0 & 0 & 0 & 0 & 5.00 & 0.0000 & SA \\
\hline $\begin{array}{l}\text { The presentation of the } \\
\text { instructional video is made } \\
\text { simple to avoid any possible } \\
\text { distractions. }\end{array}$ & 100 & 100 & 0 & 0 & 0 & 0 & 5.00 & 0.0000 & SA \\
\hline $\begin{array}{l}\text { The instructional videos have } \\
\text { an adaptive format - if the } \\
\text { learners already know it, they } \\
\text { can skip it. }\end{array}$ & 100 & 100 & 0 & 0 & 0 & 0 & 5.00 & 0.0000 & SA \\
\hline $\begin{array}{l}\text { The videos are accessible } \\
\text { both synchronously and } \\
\text { asynchronously so learners }\end{array}$ & 95 & 95 & 3 & 3 & 2 & 2 & 4.93 & 0.3258 & SA \\
\hline
\end{tabular}


need to.

The instructional videos are fast to load and does not buffer.

I usually finish watching the instructional videos because of its engaging presentations

$\begin{array}{llllll}96 & 96 & 2 & 2 & 2 & 2\end{array}$

4.94

96

$\begin{array}{lllll}96 & 2 & 2 & 2 & 2\end{array}$

4.94
0.3120

0.3120
SA

SA and designs.

\begin{tabular}{llll} 
Average & 4.98 & 0.0950 & $S A$ \\
\hline
\end{tabular}

The table above illustrates that the respondents strongly agree that the instructional videos is in high quality format, the voice of the teacher in the video is loud and clear, and that the video and voice over play synchronously (statements 1 to 3 , $M=5$ and $S D=0$ ). It is also strongly agreed that the file size of the instructional videos is enough to play it even on outdated gadgets $(M=5$ and $S D=0)$. The duration is also just enough to retain learners' attention, the presentation is made simple to avoid any possible distractions and does have an adaptive format (statements 5 to $7, M=5$ and $S D=0$ ). The respondents strongly agreed that these are accessible both synchronously and asynchronously so learners may watch it anytime they need to $(M=4.93, S D=0.3258)$, are fast to load and does not buffer $(M=4.94, S D=0.3120)$. The learners also watch the entirety of the videos because of its engaging presentations and designs $(M=4.94, S D=0.3120)$. In terms of the video quality, the results gained an average of 4.98 with a standard deviation of 0.0950 which translates to an overall rating of Strongly Agree. This shows that the learners have a positive feedback with regards to the instructional videos' quality.

In a study conducted by Dobrian, F., Sekar, V., Awan, A., Stoica, I., Joseph, D., Ganjam, A., ... \& Zhang, H. (2011) which sought to understand if and how video quality affects user engagement and how to best invest their resources to optimize video quality, it was found out that the percentage of the time spent in buffering (buffering ratio) has the largest impact on the user engagement across all types of content. It was also found out that the average bitrate plays a significantly more important role in the case of live content than a recorded content. This follows the notion that video quality plays a vital role in engaging the learners to participate actively in the learning process.

Table 4. Frequency and percentage distribution of responses on recommendations to use the instructional videos

\begin{tabular}{lcc}
\hline \multicolumn{1}{c}{ Responses } & Frequency & Percentage \\
\hline Yes, because the activities and examples are easy to understand. & 27 & $27 \%$ \\
Yes, because it's exciting and gives more motivation to learn. & 23 & $23 \%$ \\
$\begin{array}{l}\text { Yes, because it helps me understand the written texts in the } \\
\text { printed modules. }\end{array}$ & 15 & $15 \%$ \\
$\begin{array}{l}\text { Yes, because using videos in learning is very helpful especially } \\
\text { during the Modular Distance Learning. }\end{array}$ & 14 & $14 \%$ \\
Yes, because it makes me feel that I can achieve the lesson \\
objectives as stated both in the modules and instructional videos. \\
$\begin{array}{l}\text { Yes. (no reason stated) } \\
\text { (Did not answer at all.) }\end{array}$ & 12 & $12 \%$ \\
\hline
\end{tabular}

As shown in the table above, it can clearly be seen that almost all the respondents recommend the use of the instructional videos for varying reasons. Twenty-seven percent (27\%) of the responses recommends the videos because the activities and examples are easy to understand while twenty-three percent $(23 \%)$ are because of the exciting and motivational feature. Fifteen percent $(15 \%)$ of the responses recommends because it helps them understand the written texts in the printed modules and another fourteen percent (14\%) especially during the implementation of Modular Distance Learning. Twelve percent $(12 \%)$ of the responses says its because it makes them feel that they can achieve the lesson objectives while six percent $(6 \%)$ did not state their reasons and three percent $(3 \%)$ did not answer at all. The data above shows that there is a highly favourable result implying that the instructional videos used in this study is recommendable.

Parallel to the study conducted by Bajrami, L., \& Ismaili, M. (2016) which sought to explore the goals of using video material in EFL classrooms and the advantages of using video materials in EFL teaching, on the basis of which proposes a framework of teaching principles, strategies and specific tips which facilitate EFL teaching, it was found out that students find the experience of using video material to be interesting, relevant, beneficial and somewhat motivating in class. As a result, it may be suggested that both teachers and students can be involved in creative ways to incorporate different video 
materials in a variety of classroom activities to enhance learning outcomes and provide a positive classroom environment.

Table 5. Frequency and percentage distribution of responses on comments and suggestions to improve the instructional videos

\begin{tabular}{lcc}
\hline \multicolumn{1}{c}{ Responses } & Frequency & Percentage \\
\hline $\begin{array}{l}\text { The videos must also be made available offline for students who } \\
\text { have trouble connecting to the internet. }\end{array}$ & 14 & $14 \%$ \\
$\begin{array}{l}\text { There should be more real-life examples so I could fully } \\
\text { understand the learning content. }\end{array}$ & 6 & $6 \%$ \\
(No suggestions) & 80 & $80 \%$ \\
\hline
\end{tabular}

The table above shows that fourteen percent $(14 \%)$ of the responses suggested that the instructional videos must be made available offline for students who finds it hard to connect to the internet for varying reasons while another six percent (6\%) suggested to add more real-life examples. However, the majority $(80 \%)$ of the respondents did not suggest at all. The data above implies that the instructional videos used in this study have reached the standards to make it appropriate for its target audiences.

The results are parallel to the contents of a book written by Krackov, S. K. (2013) which says that giving suggestions or feedbacks is an essential component of the teaching and learning process. Giving feedbacks allows the learners and teachers to achieve both personal and learning objectives. It also gives learners insight into his or her actions and consequences.

Table 6. Summary of Values for Testing the Significant Difference Between the Pre-Assessment and Post-Assessment

\begin{tabular}{lcc}
\hline & Pre-Assessment & Post Assessment \\
\hline Total Number of Items & 50 & 50 \\
Highest Score & 24 & 48 \\
Lowest Score & 4 & 21 \\
Mean & 12.03 & 32.84 \\
Variance & 16.2112 & 40.4185 \\
Difference Between Means & \multicolumn{2}{|}{20.81} \\
Computed t-value & \multicolumn{2}{c}{43.0865} \\
Tabular Value & \multicolumn{2}{c}{1.6604} \\
Interpretation & \multicolumn{2}{c}{ Significant } \\
\hline
\end{tabular}

As illustrated in the table above, a fifty-item assessment were given before and after the use of the intervention tool. In the pre-assessment, the highest score was 24 and the lowest score is 4 while in the post assessment, the highest score increased to 48 and the lowest score also increased to 21 . The mean score during the pre-assessment 12.03 while the post assessment has a mean score of 32.84 with a mean difference of 20.81 which shows that there is an evident improvement in the outputs of the learners. The spread of the pre-assessment scores is about 16.2112 while 40.4185 in the post assessment. This implies that the score in the pre-assessment is more compact while the score in the post assessment is more dispersed. To determine whether there is a significant difference in the pre-assessment and post assessment scores, t-test was used, and the computed $t$-value is 43.0865 . This value was compared against the tabular value 1.6604. Since the computed $t$-value is higher than the tabular value, it falls on the rejection region which leads to a conclusion that there is a significant difference in the pre-assessment and post assessment scores.

The data above denotes that the use of the instructional videos in learning especially during the conduct of Modular Distance Learning has a highly positive effect on the achievement of the competencies expected from them. In resemblance to the study of Bajrami, L., \& Ismaili, M. (2016) which attempted to explore the goals of using video material in EFL classrooms and the advantages of using video materials in EFL teaching, it was concluded that video material can be used as authentic material input and as a motivational tool. In general, students find the experience of using video material to be interesting, relevant, beneficial and somewhat motivating in class. As a result, it may be suggested that both teachers and students can be involved in creative ways to incorporate different video materials in a variety of classroom activities to enhance learning outcomes and provide a positive classroom environment. 


\section{Conclusion}

Instructional videos as an intervention for the need of teachers served as a tool to continue learning at the comfort of the homes of the learners. With the data gathered in the study, it can be concluded that a video lesson must be produced to serve its purpose - to continue learning remotely, and not to make it a substitute in the absence of the teacher. Instructional videos can still be used even after the pandemic and can be stored to be used repeatedly, whenever needed. Also, its content must be well-planned and discussed to effectively transfer the information to the learners. All the exercises, activities, and concepts must be aligned to the learning competencies to ensure that the learners are going through the right track. Moreover, the quality is also found out to be necessary. Ensuring that the audio is clear, the video is stable, and both plays synchronously are just simple steps that teachers must consider to capturing the attention of the students and maintain it. Unnecessary effects and transitions, even ad-libs must be avoided because these might only serve as distractions and might hinder successful learning. On the other hand, in terms of the effectivity of the instructional videos in whole, it was found out that its use could make a great positive effect on the level of achievement of the students. This is supported by the idea that technology is now a vital part of the teaching and learning process. Using technology, whether it be video lessons or any other like music, movies, video clips or simple pictures makes learners more attentive because it can easily interest them. Teachers must also keep in mind that they are dealing with $21^{\text {st }}$ century learners so there is an arising need to use technology and adapt to the needs of the learners especially because they have different learning styles.

\section{Recommendations}

Based on the conclusions, the following recommendations are offered:

- For the learners, who are having difficulties in understanding several mathematical concepts, the results of this research as well as the output, would help them realize the beauty of Mathematics by simply watching instructional videos. Also, it can help them make ways to design a learning strategy of their own to have a better understanding of the subject matters they have to learn. They might also use and share these to their fellow learners to widen the effectiveness of the instructional videos.

- This study might help the teachers who are experiencing difficulties in facilitating learning, to create and to implement an instructional guide for an easier and better comprehension of the students. It can also help them make a better teaching strategy for a more conducive learning environment. Writing lesson exemplars and incorporating the use of instructional videos should be conducted to fully test its effectivity. Similar instructional videos can be created and used also in other subject areas discussing different subject matters.

- The group under study can use the result as a basis on how they should effectively use their knowledge and the mathematical facts they learn to their everyday lives. They would know their present learning conditions and be able to make a modification whenever necessary.

- The results of this study might also be a way to help the administrators of the schools to design a more comprehensive curriculum for the students' effective learning. By this way, administrators could achieve their school's goals and be a better provider of good education to students. Special programs must be implemented to encourage teachers to develop and adopt the use of instructional videos in their own classes, whether it be distance learning or face-to-face. Further studies also should be conducted on the use of the instructional videos not only in Mathematics but also in other disciplines.

- Finally, for the future researchers who are seeking for the related studies and concepts that they can use for their own research, it would be of great help for them to use the result of this study and incorporate it with other studies or do a parallel or follow-up study about this. Qualitative procedures in data gathering should be included or considered to increase the reliability of the results. The proposed materials may be subjected to further validation and acceptability test to assess its applicability.

\section{References}

Bajrami, L. \& Ismaili, M. (2016). The role of video materials in EFL classrooms. Procedia-Social and Behavioral Sciences, 232, 502-506

Bunag, H. (2015) Cognitive Theories and Its Application in Statistics. Southern Luzon State University. Quezon, Philippines.

Department of Education (2012) Republic Act No. 10533 An act enhancing the philippine basic education system by strengthening its curriculum and increasing the number of years for basic education, appropriating funds therefor and for other purposes.

Dobrian, F., Sekar, V., Awan, A., Stoica, I., Joseph, D., Ganjam, A., ... \& Zhang, H. (2011). Understanding the impact of video quality on user engagement. ACM SIGCOMM Computer Communication Review, 41(4), 362-373.

Krackov, S. K. (2013). Best Practices for Producing Video Content for Teacher Education. Contemporary Issues in Technology and Teacher Education, 10(2), 247-256. Waynesville, NC USA: Society for Information Technology \& Teacher Education. Retrieved November 20, 2020.

Mathumbu, D., Rauscher, W., \& Braun, M. (2014). Knowledge and cognitive process dimensions of Technology teachers' lesson objectives. South African Journal of Education, 34(3).

Richards, J. C. \& Bohlke, D. (2011). Video cases in elementary science teacher preparation. In J. Brophy (Ed.), Using video in teacher education: Advances in research on teaching (Vol. 10; pp. 103-130). Oxford, England: Elsevier Ltd. 
Shafie, A. Shahdanb, R. \& Liew, P. (2010). Video content authentication techniques: a comprehensive survey. Multimedia Systems, 24(2), 211-240.

Shimizu, K., Kaur, J., Huang, C. \& Clarke, M. (2010) Prospective Secondary Mathematics Teachers' Pedagogical Knowledge for Teaching the Estimation of Length Measurements.

Watson, A. B. \& Gable, F. (2012). An analysis on the use of video materials in college English teaching in China. International Journal of English Language Teaching, 2(1), 23-28.

Watson, A. B. \& Ohtani, A. (2015). Digital video quality metric based on human vision. Journal of Electronic imaging, 10(1), 20-29. 